\title{
Lysosome-Associated Membrane Glycoprotein 2
}

National Cancer Institute

\section{Source}

National Cancer Institute. Lysosome-Associated Membrane Glycoprotein 2. NCI

Thesaurus. Code C116024.

Lysosome-associated membrane glycoprotein 2 (410 aa, $\sim 45 \mathrm{kDa}$ ) is encoded by the human LAMP2 gene. This protein plays a role in lysosome function. 